\title{
19. PETROLOGY OF SILICEOUS ROCKS RECOVERED FROM MARGINAL SEAS OF THE WESTERN PACIFIC, LEG 31, DEEP SEA DRILLING PROJECT
}

\author{
Robert E. Garrison, Stephen M. Rowland, Lawrence J. Horan, and J. Casey Moore, \\ Earth Sciences Board, University of California, Santa Cruz, California
}

\section{INTRODUCTION}

Siliceous sedimentary rocks of Tertiary age were recovered at three of the nine sites drilled during Leg 31 (Table 1). Only relatively small amounts of lithified material were retrieved, but these rocks are particularly interesting because they include three distinct types of siliceous rock and because each type occurs with a distinct sediment lithology. The kinds of rocks sampled are (with lithologies of the associated soft sediments in parentheses): nodular chert (nannofossil chalk ooze), radiolarian porcelanite (brown clay), and diatom porcelanite (diatom ooze) (Figures 1-8).

These rocks are significant also because each different variety appears to record an early stage of diagenesis for siliceous rocks of the kinds now found in stratigraphic assemblages on land. In addition, these rocks occur entirely within the marginal ocean basin setting; their detailed description thus adds to the total characterization of sedimentary sequences formed in this setting.

Marine geologists frequently apply the term "chert" to any siliceous rock recovered from the ocean basins, but its usage herein is restricted to rocks composed dominantly or entirely of quartz. The term "porcelanite" is used for less dense rocks composed mainly of cristobalite and having a subvitreous or porcelaneous luster following the recommendation of Calvert (1974).

\section{RADIOLARIAN PORCELANITE, SITE 291}

Site 291 lies on the outer swell of the Philippine Trench along the western margin of the Philippine Basin. In addition to brown clay, cores from this site include minor amounts of nannofossil and radiolarian ooze. Silicified radiolarian porcelanite occurs at a subbottom depth of 103 meters in intimate association with radiolarian-bearing, zeolite-rich clay of middle Eocene age. Two silicified porcelanite intervals cored in Core 4, Section 4 are each 5-6 cm thick, with boundaries parallel to bedding; thus they appear to be layered rather than nodular.

These porcelanites are very hard and have a conchoidal to slightly hackly fracture pattern. Their reddish color is a striking character; the specific coloration varies from reddish black (1OR 2/1) to dusky red (1OR $3 / 2$ ), and a few layers and patches have a punky, altered appearance with an olive-yellow color $(2.5 Y$ 6/6). The rocks have a greasy to porcelaneous luster, and they contain discontinuous laminae, and small, irregular mottles. The measured density of one specimen is 2.08 .

In thin section, these rocks consist of very poorly preserved microfossil remains, without a trace of original shell wall, dispersed through a fine-grained matrix (Figure 4a). The microfossils are of the approximate size and shape of radiolarian tests, but the quality of preservation does not permit unequivocal

TABLE 1

Siliceous Rocks Recovered During Leg 31, DSDP

\begin{tabular}{|c|c|c|c|c|c|c|}
\hline $\begin{array}{l}\text { Sample } \\
\text { (Working } \\
\text { Number) }\end{array}$ & $\begin{array}{c}\text { Sample } \\
\text { (Interval } \\
\text { in } \mathrm{cm} \text { ) }\end{array}$ & Lithology & $\begin{array}{l}\text { Total } \\
\text { Depth } \\
\text { (m) }\end{array}$ & $\begin{array}{l}\text { Depth } \\
\text { Below } \\
\text { Sea } \\
\text { Floor } \\
(\mathrm{m}) \\
\end{array}$ & Age & Associated Sediment \\
\hline $\begin{array}{l}\text { MOR6 } \\
\text { MOR7 } \\
\text { MOR8 }\end{array}$ & $\begin{array}{l}291-4-4,12-17 \\
291-4-4,15-17 \\
291-4-4,66-72\end{array}$ & $\begin{array}{l}\text { Radio: } \\
\text { larian } \\
\text { porcelanite }\end{array}$ & $\begin{array}{l}5340 \\
5340 \\
5341\end{array}$ & $\begin{array}{l}103 \\
103 \\
103\end{array}$ & $\begin{array}{l}\text { Middle } \\
\text { Eocene }\end{array}$ & $\begin{array}{l}\text { Porcelanite interlayered in } \\
\text { brown clay, planar, contacts } \\
\text { parallel to bedding. Assoc- } \\
\text { iated brown clays contain } \\
\text { Radiolaria, zeolites, and } \\
\text { iron oxides }\end{array}$ \\
\hline $\begin{array}{l}\text { MOR9 } \\
\text { MOR10 } \\
\text { MOR11 } \\
\text { MOR12 } \\
\text { MOR13 } \\
\text { MOR14 } \\
\text { MOR15 }\end{array}$ & $\begin{array}{l}292-38, \text { CC } \\
292-38, \text { CC } \\
292-38-2,135-139 \\
292-38-2,103-105 \\
292-39-1,84-89 \\
292-39-3,102-107 \\
292-39-3,34-36\end{array}$ & $\begin{array}{l}\text { Chert } \\
\text { nodules } \\
\text { in } \\
\text { nanno- } \\
\text { fossil } \\
\text { chalk }\end{array}$ & $\begin{array}{l}3316 \\
3316 \\
3309 \\
3309 \\
3317 \\
3320 \\
3319\end{array}$ & $\begin{array}{l}358 \\
358 \\
351 \\
351 \\
359 \\
362 \\
361\end{array}$ & $\begin{array}{l}\text { Late } \\
\text { Eocene }\end{array}$ & $\begin{array}{l}\text { Chert occurs in lenses and } \\
\text { irregular patches in sequences } \\
\text { of chalk ooze. Minor amounts } \\
\text { of Radiolaria were consistently } \\
\text { present down hole until chert } \\
\text { occurs (Radiolaria possibly } \\
\text { dissolved) }\end{array}$ \\
\hline MOR86 & $302-15, C C$ & $\begin{array}{l}\text { Diatom } \\
\text { porcelanite }\end{array}$ & 2690 & 276 & $\begin{array}{l}\text { Late } \\
\text { Miocene }\end{array}$ & $\begin{array}{l}\text { Associated diatom ooze gen- } \\
\text { erally unlithified. }\end{array}$ \\
\hline
\end{tabular}




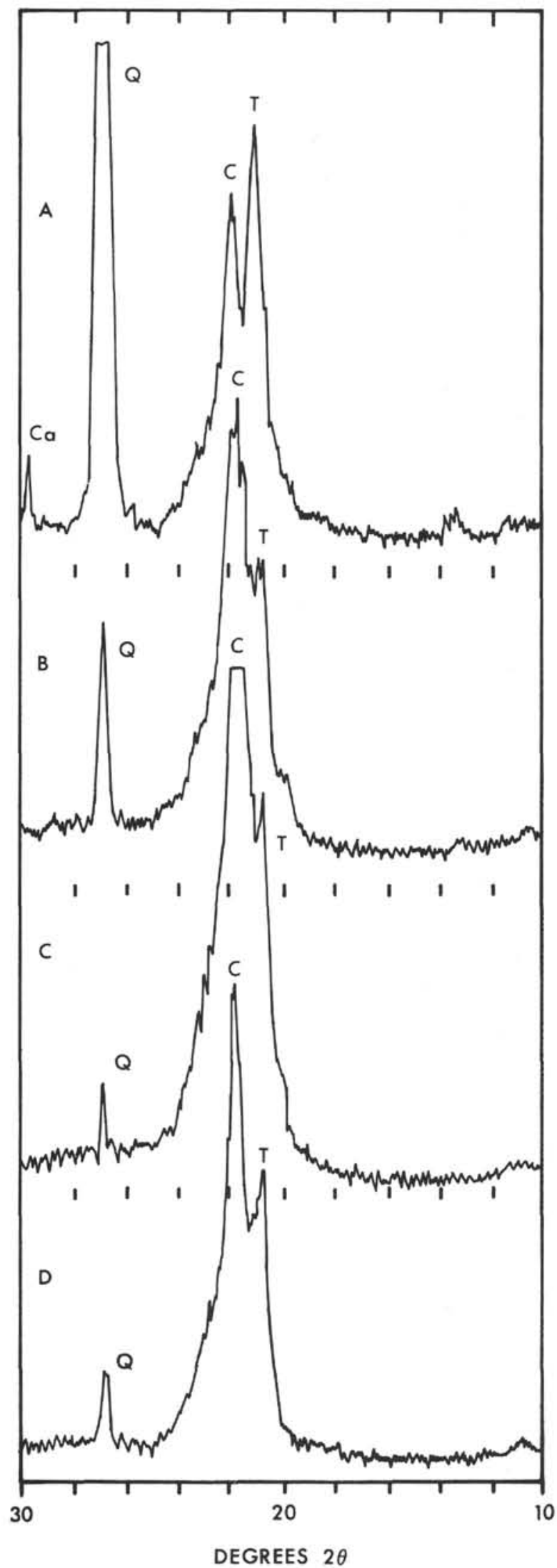

Figure 1. X-ray diffraction patterns for siliceous rock samples recovered on Leg 31. (a) Silicified chalk from Sample 292-38-2, 103-105 cm, (b) Radiolarian porcelanite from Sample 291-4-4, $12-17 \mathrm{~cm}$; (c) Diatomaceous porcelanite from Sample 302-15, CC; (d) Cristobalitic chert from the Monterey Formation near Lompoc, Santa Barbara County, California, $Q=$ quartz; $C=$ cristobalite; $T=$ tridymite; $C a=$ calcite. Conditions: CuK $\alpha$ radiation, Ni filter, $35 \mathrm{kv}, 20 \mathrm{ma}$, scintillation detector.
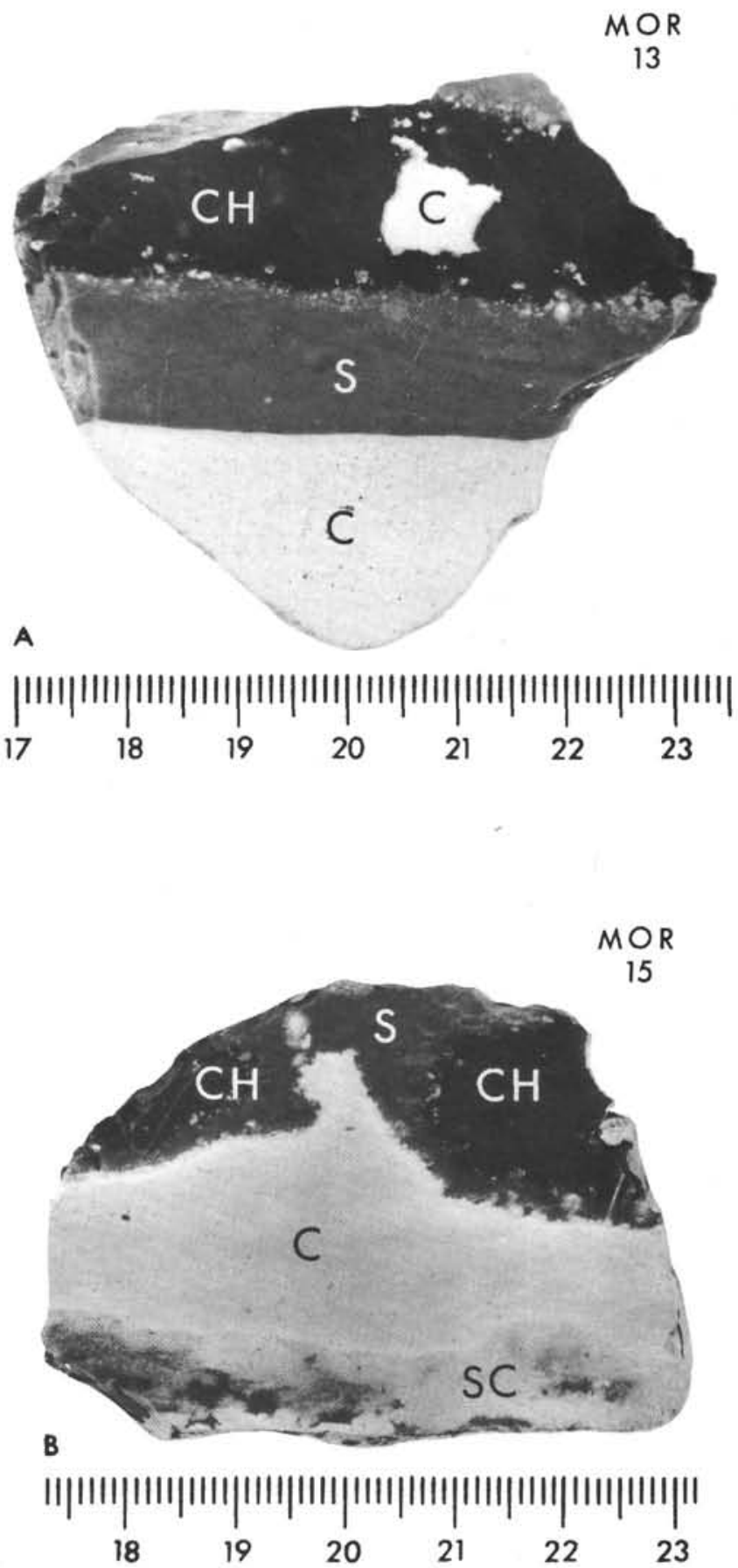

Figure 2. Cut sections of nodular cherts associated with chalk oozes, Site 292, Core 39. (a) From Sample 39-1, 84-89 cm; (b) From Sample 39-3, 34-36 cm. The letter $C$ designates unsilicified but coherent white chalk and SC indicates light brownish-gray, partly silicified chalk. $S$ indicates zones of brown, intensely silicified chalk which contains both quartz and cristobalite (see Figure 1a). $\mathrm{CH}$ is dark brown chert composed of microcrystalline quartz. Centimeter scales. 
PETROLOGY OF ROCKS RECOVERED FROM MARGINAL SEAS, WESTERN PACIFIC

$1.5 \mathrm{~cm}=500$ microns
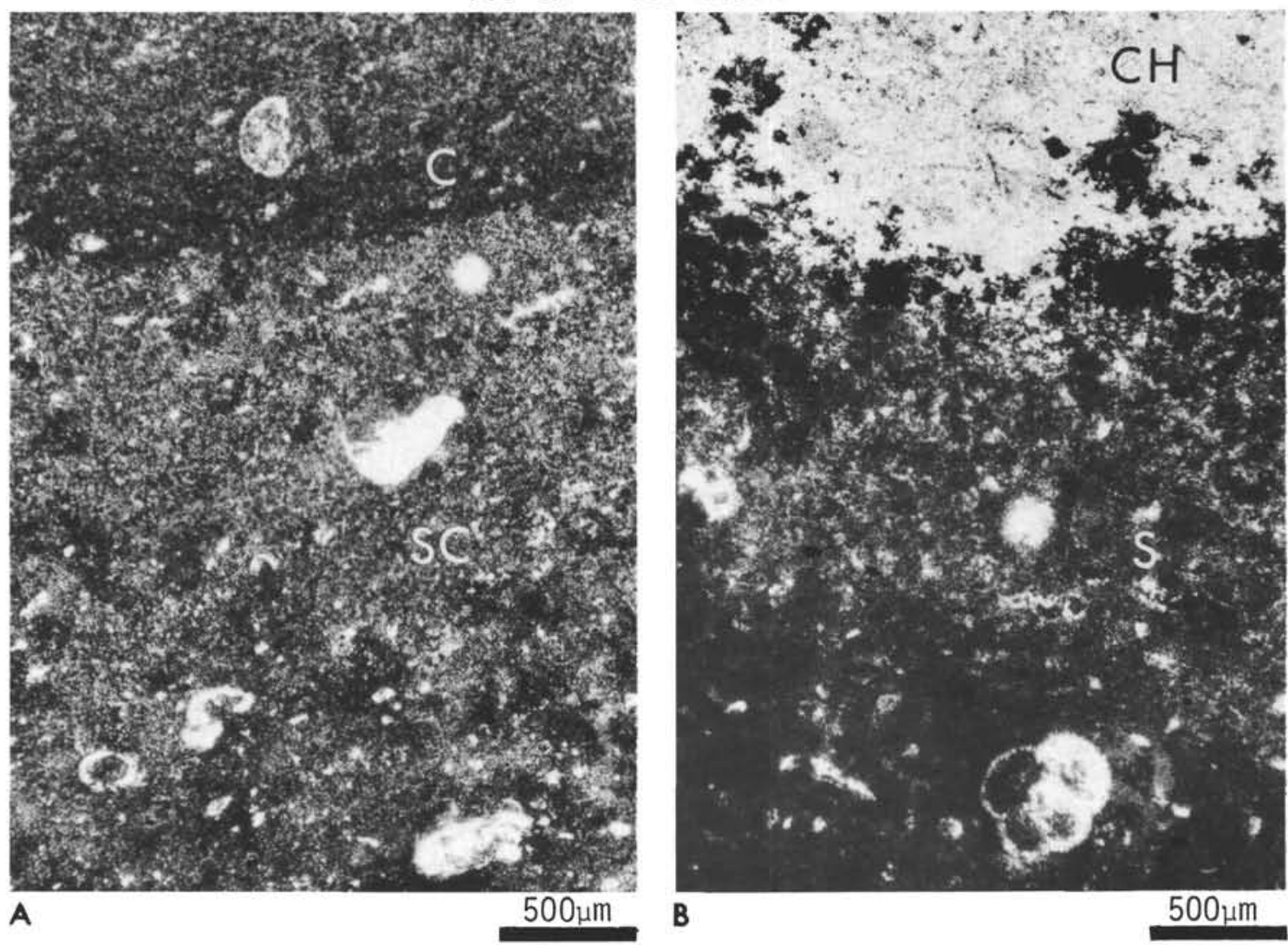

A

$500 \mu \mathrm{m}$
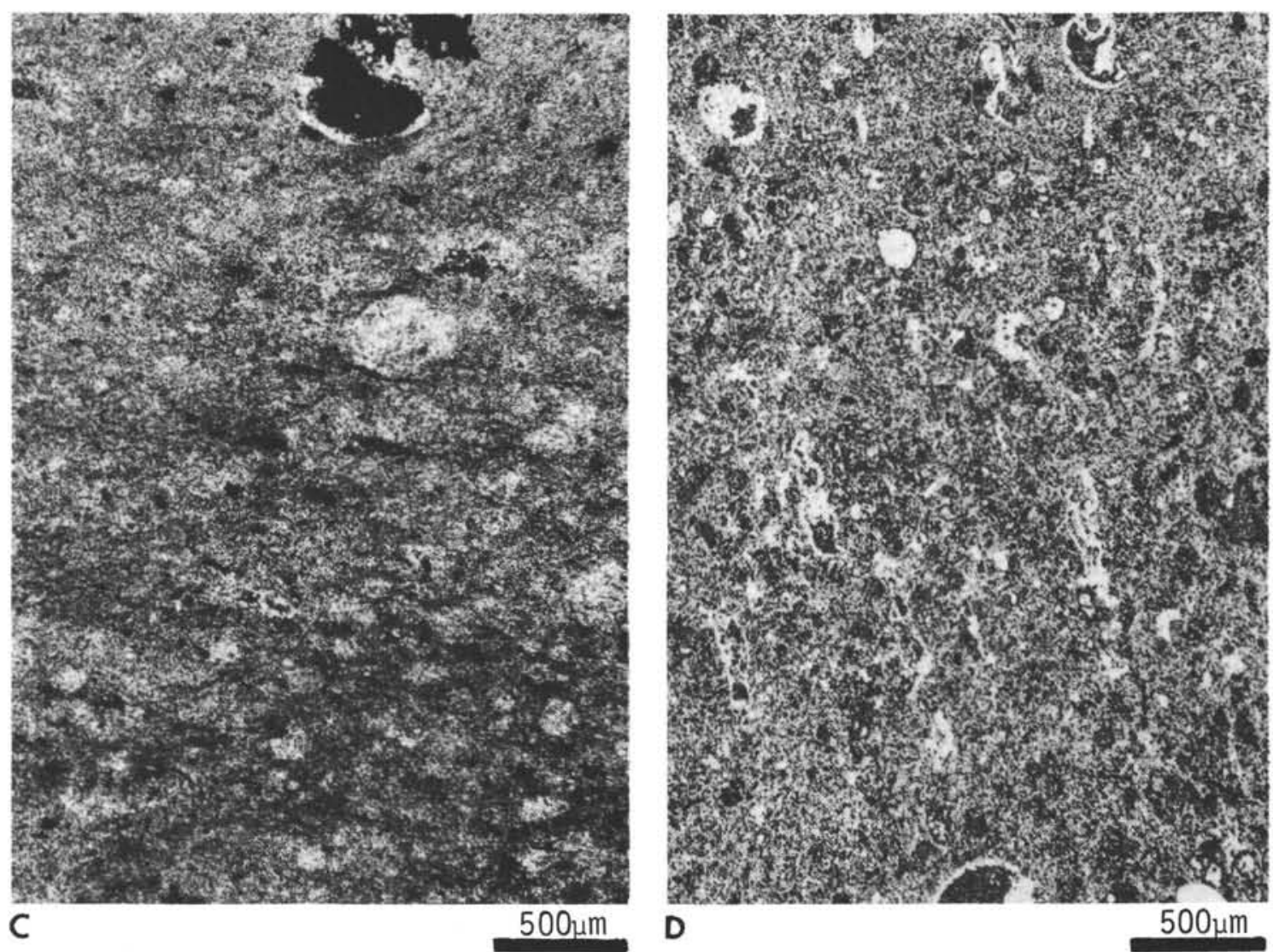

Figure 3. Photomicrographs of silicified chalks and chert, from Site 292, Core 39. (a) Contact between chalk above (C) and partly silicified chalk (SC) below; the latter zone contains small areas (dark) of unreplaced chalk. Section 3, Interval 102-107 $\mathrm{cm}$. (b) Contact between silicified chalk $(\mathrm{S})$ and chert $(\mathrm{CH})$. Microfossil tests are replaced by secondary quartz. Section 3, Interval $34-36 \mathrm{~cm}$. (c) Chert (zone CH in Figure 2a). Scattered diffuse outlines of replaced microfossils and irregular patches of silicified chalk. Section 1, Interval $84-89 \mathrm{~cm}$. (d) Zone of intensely silicified chalk (zone S in Figure 1a). Light colored areas are silicified microfossils (mainly foraminifera). Bedding is vertical in this photomicrograph; horizontal in $a, b$, and $c$. 

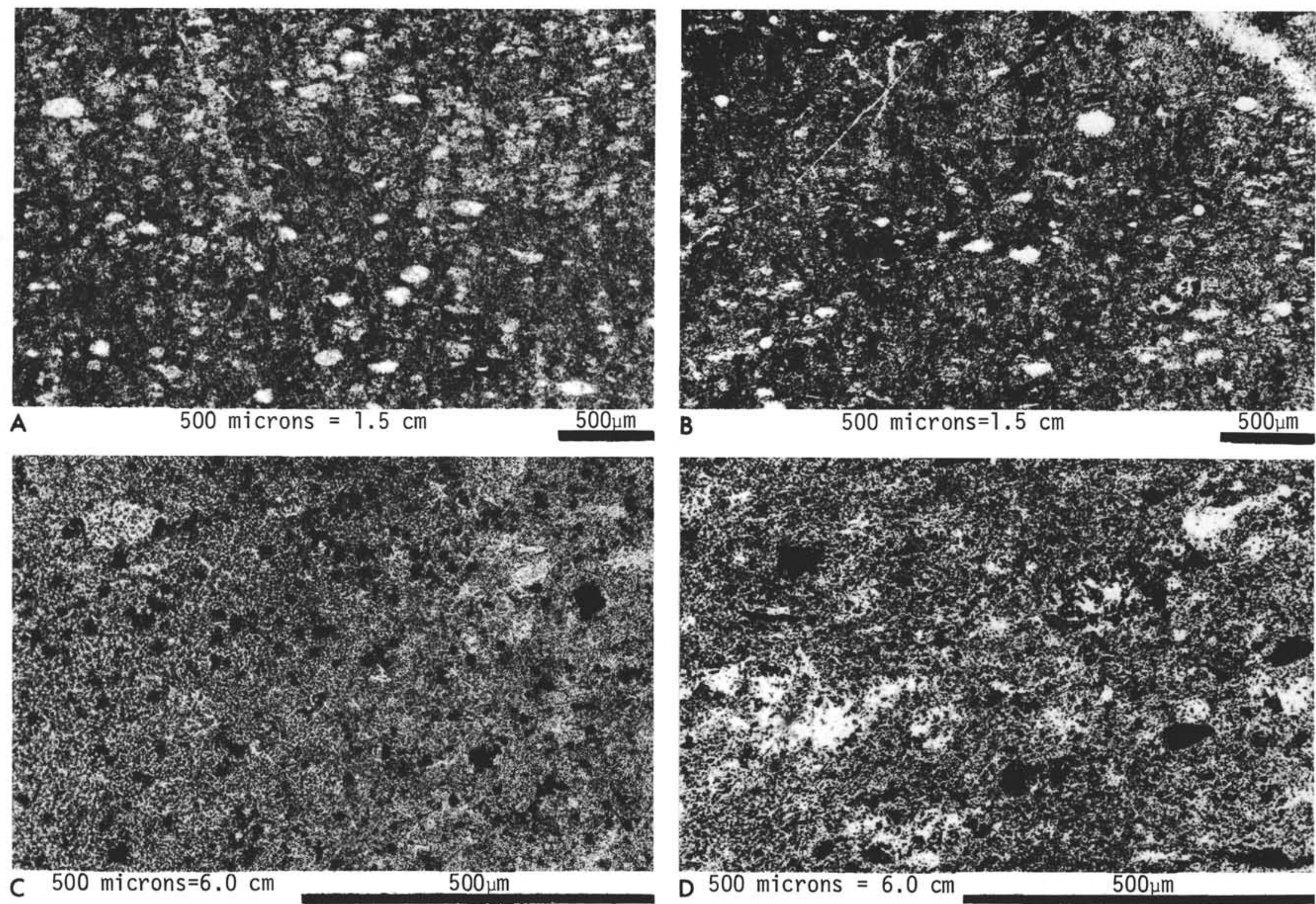

Figure 4. Photomicrographs of radiolarian mudstone and chert. (a) and (c) are of Eocene radiolarian porcelanite from Sample 291-4-4, 12-17 cm (b) and (d) are of a Mesozoic radiolarian chert from the Franciscan Formation near Sausalito, Marin County, California. Scale bars represent $500 \mu$. (a) Poorly preserved microfossils (Radiolaria?) in this Eocene porcelanite are clear, elliptical patches of fine-grained cristobalite. The matrix of this rock is illustrated in (c). (b) Note resemblance of this Franciscan bedded chert to the Eocene porcelanite illustrated in (a). Poorly preserved microfossils (Radiolaria) are molds filled by secondary quartz (elliptical white patches), and several small quartz veins (white) cut the specimen. (c) Detailed view of matrix in the Eocene porcelanite from Site 291. Small grains of iron oxides (dark patches) are dispersed through a very fine-grained, cristobalitic matrix. (d) Detailed view of matrix in Franciscan bedded chert. Irregular patches and grains of iron oxides (dark) are dispersed through a matrix of microcrystalline quartz (light). 

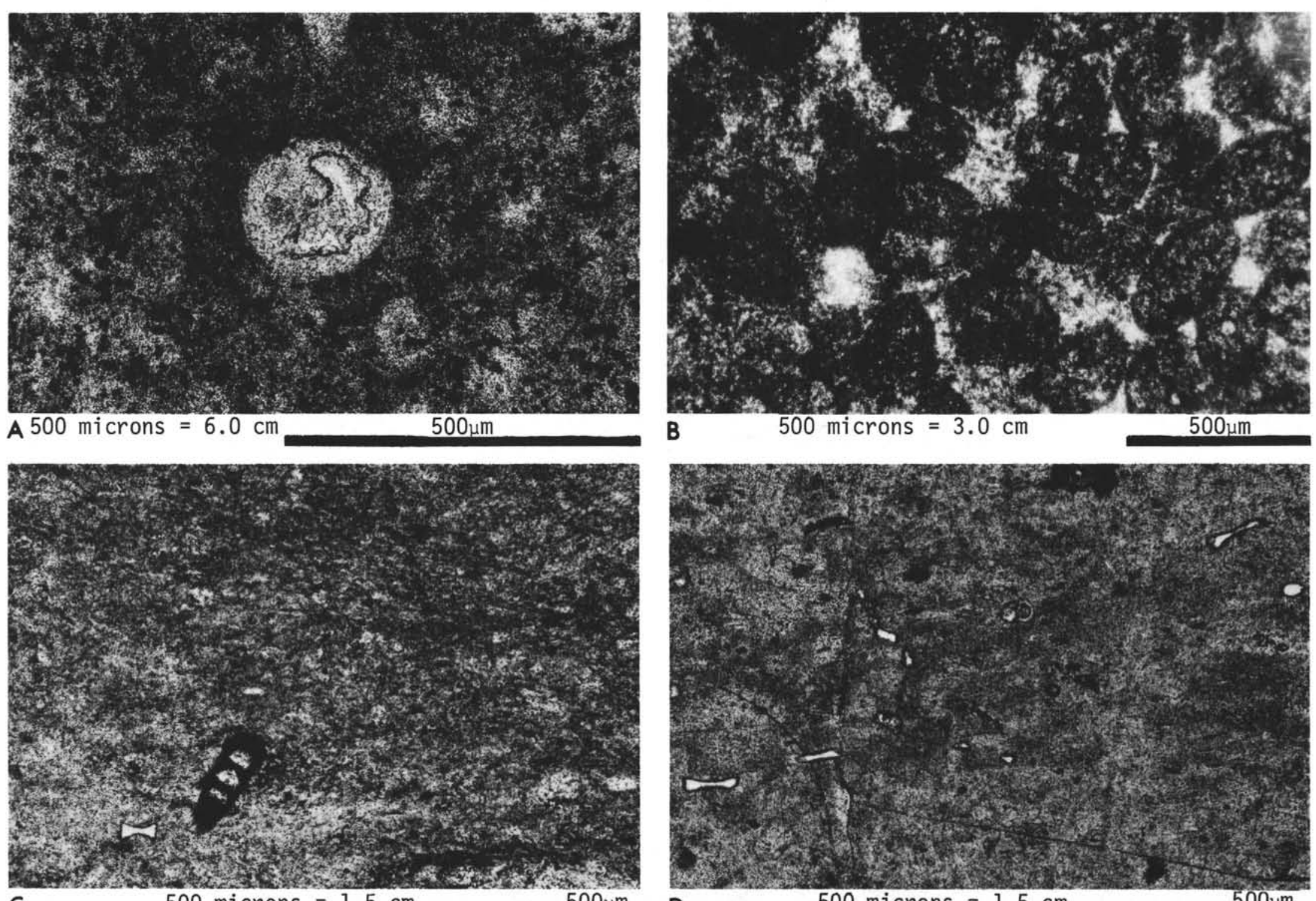

C

500 microns $=1.5 \mathrm{~cm}$

$500 \mu \mathrm{m}$

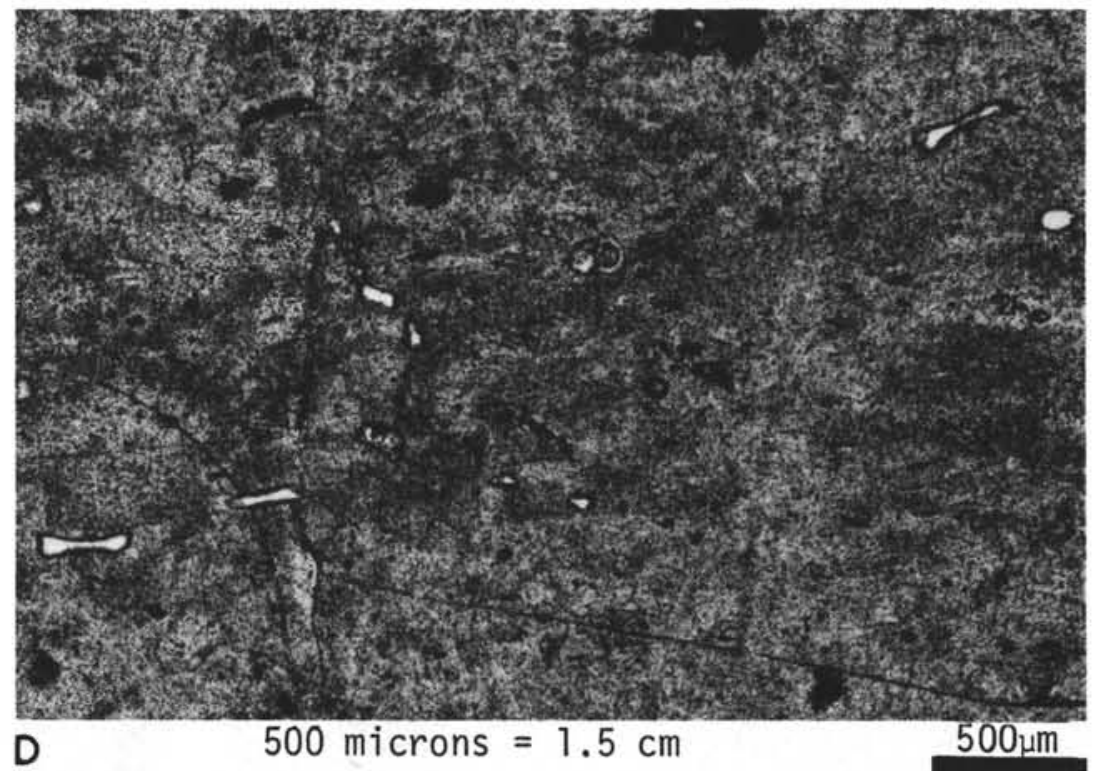

Figure 5. Photomicrographs of siliceous rocks from Sites 291 and 302 and from the Monterey Formation of California. Scale bars represent 500 $\mu$ (a) Radiolarian mold in Eocene porcelanite (Sample 291-4-4, 66-72 cm). The mold is filled by an outer rim of fine-grained cristobalite and a core of transparent chalcedonic quartz. Fine cristobalitic matrix contains numerous small grains of iron oxides (black spots). (b) Different portion of the same sample illustrated in (a), showing elliptical pellets. The pellets are composed of cristobalitic matrix material and are cemented by clear (white) to somewhat murky cristobalite. (c) Miocene porcelanite from Sample 302-15, CC. Note paucity of microfossils in the cristobalitic matrix, except for the diatom and foraminiferal tests at lower left. The diatom mold is filled with fibrous, chalcedonic quartz. (d) Sample of cristobalitic chert from the Monterey Formation, Miocene; sample is from near Lompoc, Santa Barbara County, California. Scattered diatom molds (filled with fibrous chalcedonic quartz) reside in fine cristobalitic matrix. An X-ray diffractogram of this sample is illustrated in Figure $1 \mathrm{~d}$. 
R. E. GARRISON, S. M. ROWLAND, L. J. HORAN, J. C. MOORE
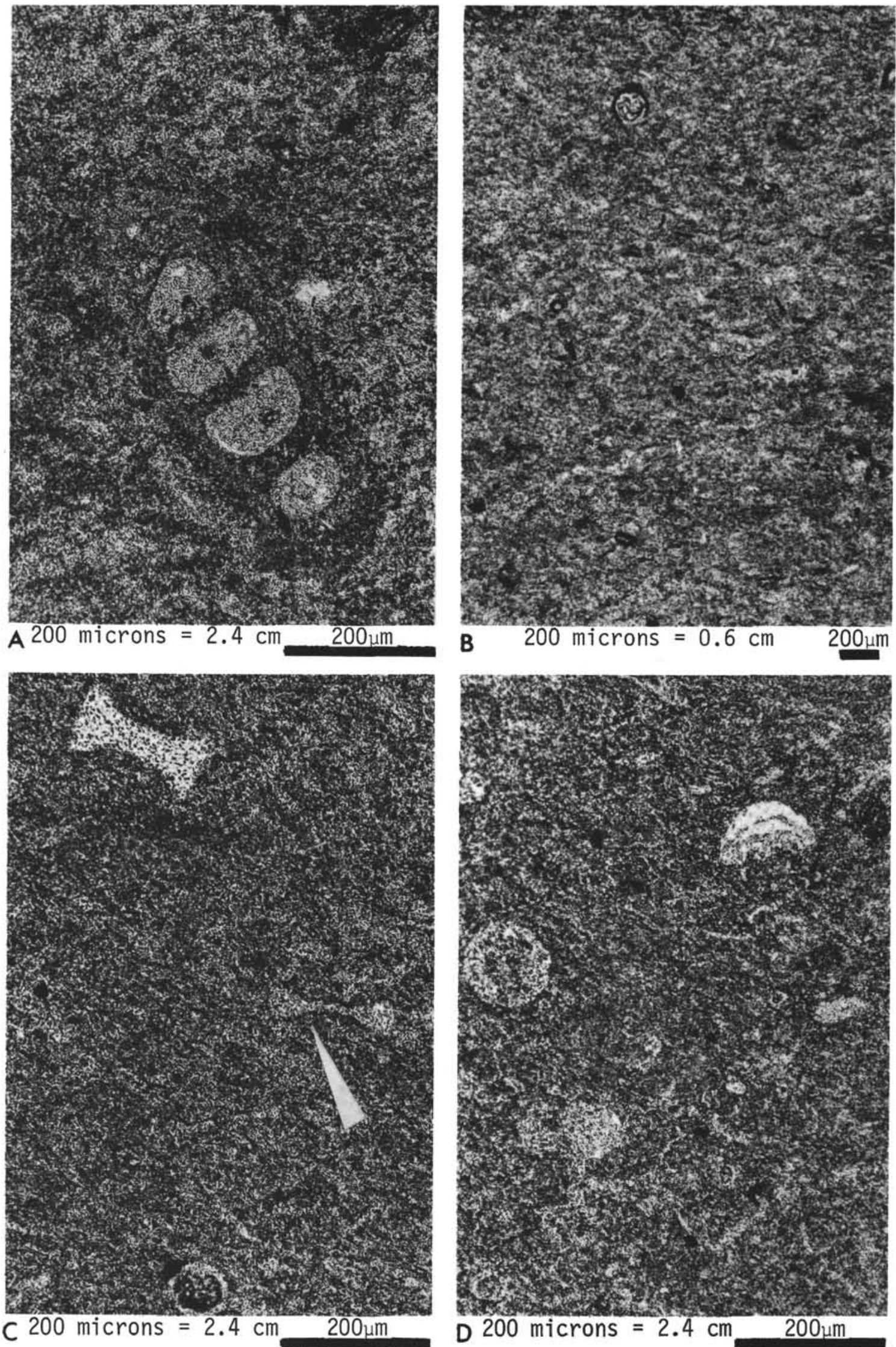

Figure 6. Photomicrographs of Miocene diatrom procelanite, Sample 302-15, CC. (a), (c), and (d) are of an acetate peel; (b) is of a thin section. (a) Foraminifera test in fine-grained cristobalitic matrix (see Figure 5c for lower magnification view). The test wall is replaced by fine cristobalite, and shell chambers likewise are filled by fine cristobalite. (b) Low magnification view of cristobalitic matrix containing dispersed, partly pyritized microfossil (diatom?) shells. (c) Prominent diatom mold filled by fine cristobalite at upper left, ghost-like cirstobalitic diatom cast at right center (arrow). (d) Poorly preserved diatom ramains in cristobalitic matrix. Note variation in the distinctness of the microfossils. Most are cristobalite-filled molds, but the diatom mold toward upper right is partly filled by chalcedonic quartz (whtie). 

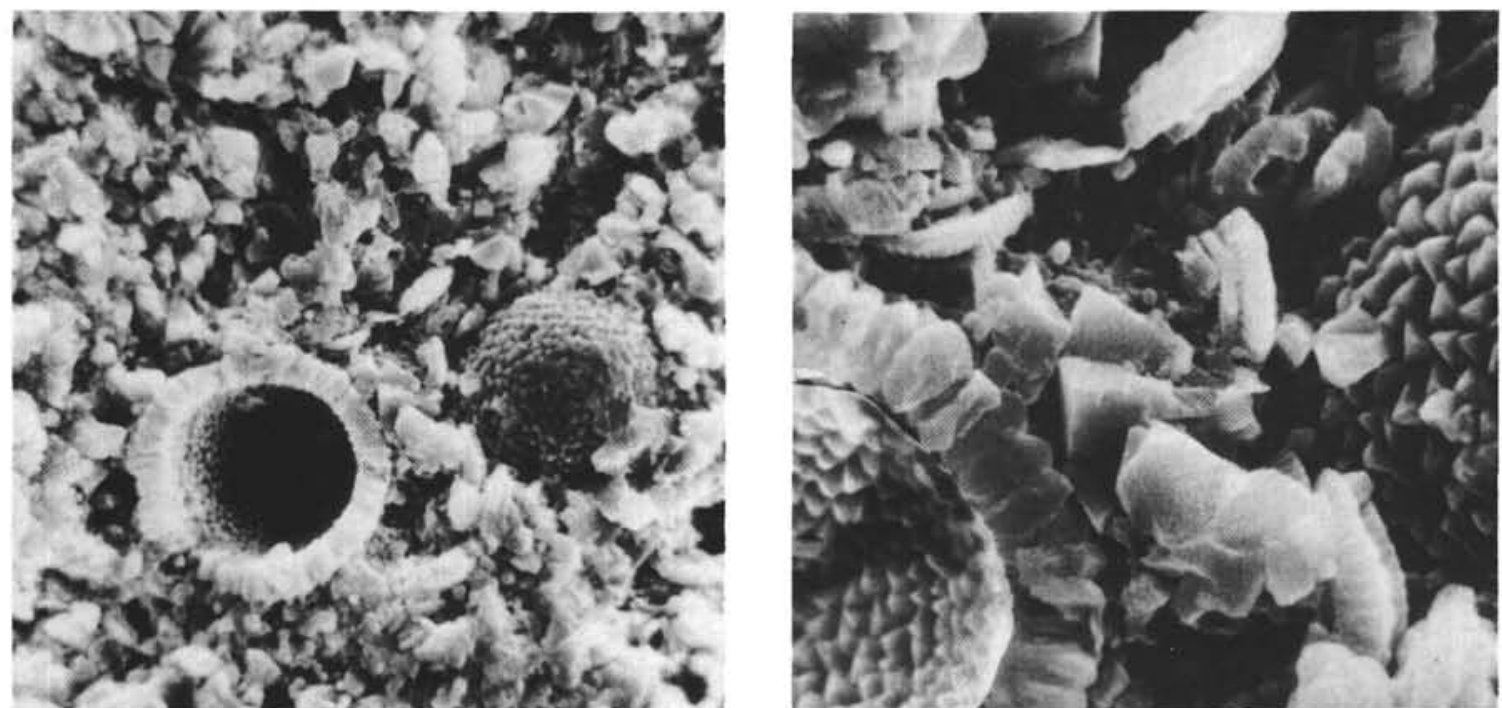

A 3 microns $=1.0 \mathrm{~cm}$
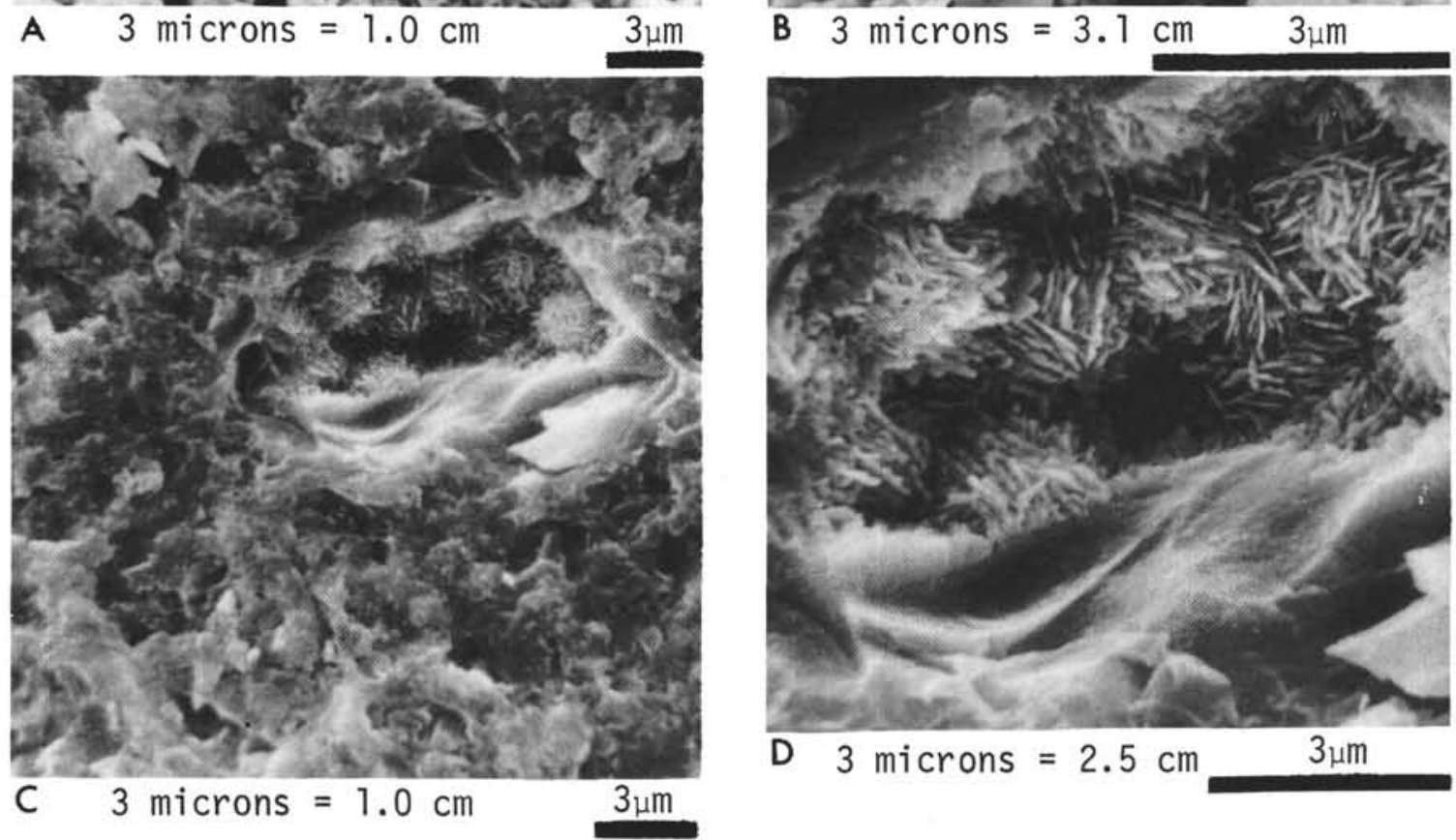

Figure 7. Scanning electron micrographs of chalk and diatom porcelanite. Scale bars represent $3 \mu$ (a) and (b) are from hard Eocene chalk adjacent to chert lens at Site 291. Note growth of secondary calcite crystals on interior and exterior of foraminiferal tests. Note also the presence of subhedral to euhedral calcite crystals between coccoliths (best seen in b). (c) and (d) are of Miocene diatom porcelanite from Site 302. In (c) a small cavity (possibly the interior of a microfossil) is partly filled by lepispheres of fibrous cristobalite. (d) shows details of the lepispheres. In (c), note the surrounding, fine-grained and somewhat poorly resolved matrix of bladed or platy cristobalite. See Figure 8 for more precisely resolved views of this matrix.

identification in many instances. The microfossils occur chiefly as molds filled by fine-grained, translucent silica (probably cristobalite) with very low birefringence; a very few molds have partial fillings of clear, length-fast, fibrous chalcedonic quartz (Figure 5a). Most of the molds have elliptical cross-sections with long axes parallel to bedding, possibly the result of compactional flattening prior to complete filling of the molds by cristobalite.

The porcelanite is comprised of about $30 \%-40 \%$ poorly preserved microfossil remains, $60 \%-70 \%$ fine-grained matrix. Also present are scattered, very small amounts $(\ll 5 \%)$ of phosphatic fish debris, some of which has very irregular shape and shows breakage, possibly due to compactional crushing.

The dominant matrix has a murky brownish appearance and is difficult to resolve in thin section. It appears to be a mixture of cryptocrystalline cristobalite with very low birefringence, dispersed iron oxides, and possibly some clay minerals. The matrix shows a strong length-slow orientation parallel to bedding when the polarizing lenses are crossed and a first-order red plate 

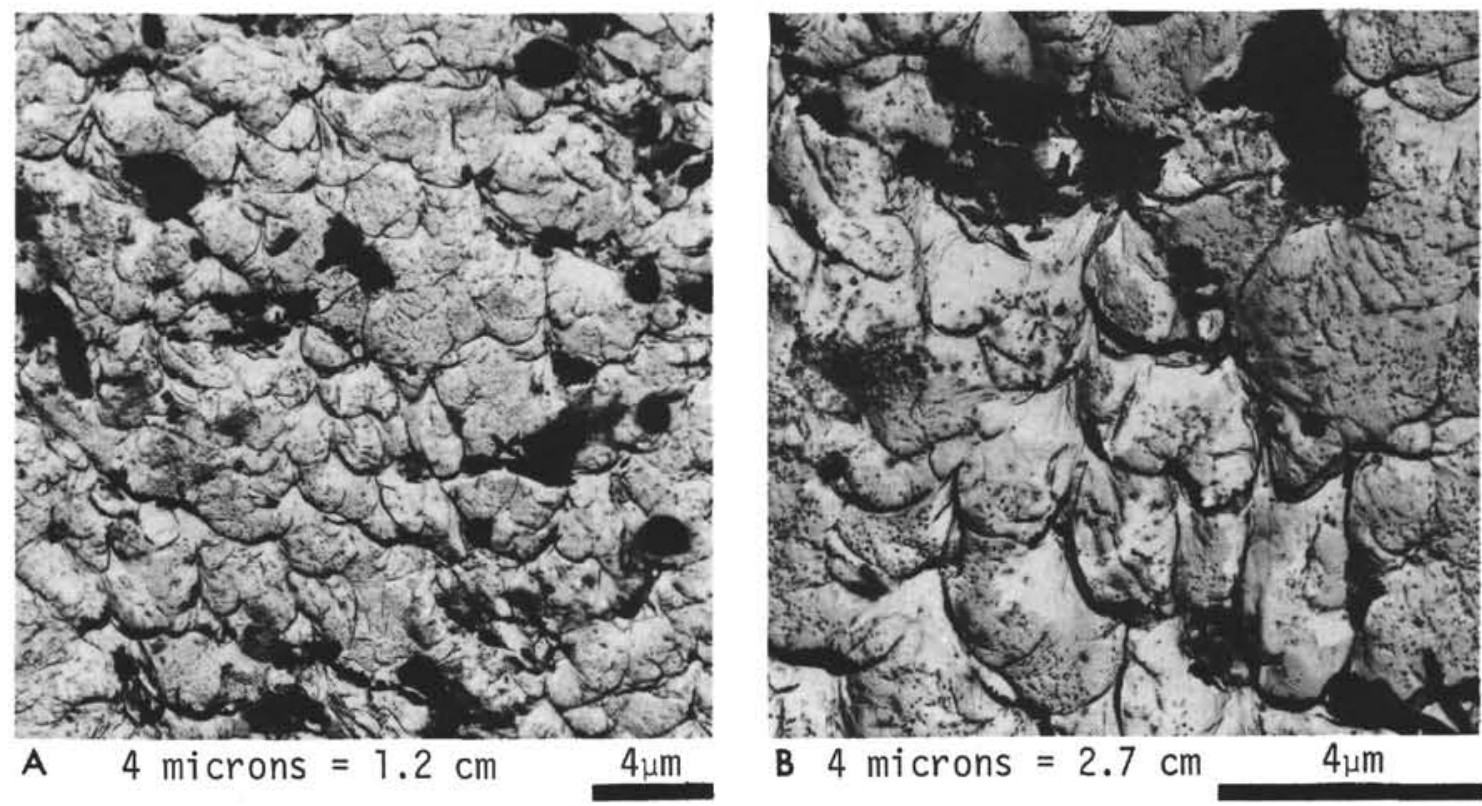

Figure 8. Transmission electron micrographs of the cristobalitic matrix of Miocene diatom porcelanite from Site 302. The scale bars represent $4 \mu$. (a) Somewhat bladed or platy crystals of cristobalite. Dark spots are material which was extracted during the replication process and are opaque to the electron beam. (b) Detail of (a). The small dark spots on the crystal surfaces are probably inclusions (possibly fluid inclusions) which were etched out during sample preparation.

inserted. Presumably this reflects a preferred orientation of the cristobalite crystallites in the matrix. Iron oxides occur in fine-grained aggregates that have a range of size and shape. Most occurs as small $(8-10 \mu)$ clusters, which are rather evenly distributed through the cristobalitic matrix (Figures $4 \mathrm{c}$ and $5 \mathrm{a}$ ). Some aggregations of redbrown iron oxides, however, attain a maximum size of about $200 \mu$.

Parts of porcelanite Sample MOR 8 (Table 1) contain distinct elliptical pellets composed of cryptocrystalline cristobalite, and iron oxides (Figure $5 \mathrm{~b}$ ). These pellets are $500-600 \mu$ in maximum dimension. A relatively clear cristobalitic matrix lies between the pellets and in places appears to be a pore-filling cement. These are probably fecal pellets. Since they seem to retain their original shape and show no overt signs of deformation, it is probable that they became lithified and possibly cemented prior to the onset of compactional stresses which caused grain flattening in other samples of these porcelanites.

A few very thin $(<20 \mu)$, inconspicuous veins filled by cristobalite record postlithification stresses imposed on the porcelanite. These are perhaps fractures induced by compactional stresses or by lithification shrinkage, or a combination of these factors.

An X-ray diffractogram of one of these radiolarian porcelanites is shown in Figure 1B. The quartz indicated on this trace resides in the few microfossil molds filled by fibrous chalcedonic quartz. The dominant mineral is disordered cristobalite which forms the matrix and fills most of the radiolarian molds. This low-temperature cristobalite, which corresponds to the material called "lussatite" by many authors (Flörke, 1955; see review in Calvert, 1974), shows stacking disorder which produces
$\mathrm{X}$-ray peaks attributable to tridymite. In the Eocene porcelanite herein described, a major broad reflection is centered at $21.75^{\circ} 20$, and subsidiary one at $20.86^{\circ} 20$ (Figure $1 \mathrm{~b}$ ); these correspond to $d$-spacings of $4.083 \AA$ (cristobalite) and $4.255 \AA$ (tridymite), respectively.

Petrographically there is a remarkable resemblance between these Eocene radiolarian porcelanites and the bedded radiolarian cherts of many geosynclinal assemblages. Figure 4 compares an Eocene porcelanite from Site 291 with a red radiolarian chert of Mesozoic age from the Franciscan Formation of California. Both rocks contain very poorly preserved radiolarian remains and fine-grained iron oxides dispersed through finegrained, siliceous matrices (Figures $4 a, 4 b, 4 c, 4 d$, and $5 \mathrm{a})$. The major difference is the mineralogical form of the silica, the Eocene porcelanite being predominantly fine-grained disordered cristobalite, the Franciscan chert, mostly microcrystalline quartz.

The Eocene siliceous porcelanites occur interlayered with brown, radiolarian-bearing clays that contain significant zeolites and iron oxides. This associated has also been reported for other silicified porcelanites at a number of DSDP Pacific sites (e.g., Pimm et al., 1971; Heath and Moberly, 1971; Heath, 1973; Lancelot, 1973). The porcelanites may in fact have been originally deposited as clays of this kind which became secondarily silicified during burial diagenesis. If they form in this manner, a major question is the source of the abundant silica in the porcelanite. An obvious possibility is dissolution and reprecipitation of biogenic silica, as suggested by numerous workers. In addition, a supply of silica released during burial diagenesis of clay minerals and zeolites cannot be excluded for these porcelanites (Towe, 1962; Keene and Kastner, 1974). According to 
Keene and Kastner (1974), the transformation of montmorillonite rich in iron to hydrous mica could yield to the surrounding sediment free silica as well as iron oxide. The latter might be the source for the fine-grained iron oxides in the matrix of these porcelanites (Figures $4 \mathrm{c}$ and $5 \mathrm{a})$.

\section{NODULAR CHERT, SITE 292}

Site 292 is located on the Benham Rise, a small midplate high east of Luzon in the Philippine Basin. Nodular chert at this site occurs within calcareous sediment in the lower portion of a monotonous nannofossil ooze-chalk sequence at a subbottom depth of 358-361 meters. This chert is of Late Eocene age and has replaced chalk ooze. The nodular morphology is evident on cut core surfaces (Figure $2 b$ ) where most chert and silicified chalk bodies are lenticular and pinch out laterally. The appearance of the chert coincides with the down-hole disappearance of Radiolaria, implying dissolution of their amorphous silica tests to form chert. Because volcanic ash layers also occur interlayered with the chalk in this part of the section, a source of silica from alteration of volcanic glass cannot be excluded.

The replacement origin of this chert is also apparent in both hand specimens and thin sections from the scattered residual patches of incompletely replaced chalk within chert (Figures $2 a$ and $2 b$ ), from the presence of silicified foraminiferal shells (Figure 3), and from the transitional nature of the change from unsilicified chalk through partly silicified chalk to chert. Details of this sequence are illustrated in Figures 2 and 3. Adjacent to the silicified nodules, the white chalk is hard and lithified (C on Figures 2a, 2b, and 3a), but there is no replacement of calcite by silica.

Lying between unsilicified chalk and true quartzose chert is a zone of either partly or completely silicified chalk (indicated by the letters SC or S in Figures 2 and 3 ) in which some textures of the chalk survive. The contact between these silicified zones and the unreplaced chalk is generally even and very sharp; in some instances it is so abrupt that half a foraminifera test may be replaced by quartz, while the other half is unreplaced. The silicified chalk zones vary in color from light gray (10YR 7/1) to light brownish-gray (10YR 6/2) to brown (10YR 5/3), and frequently there is extensive color mottling of these shades within the zone. The luster is slightly vitreous to greasy, and the fracture is hackly to subconchoidal.

In thin sections through these silicified chalk zones, quartz completely replaces tests of planktonic foraminifers (Figures 3a, 3b, and 3d). The tests vary from distinct and undistorted (see lower part of Figure $3 \mathrm{~b})$ to indistinct and ghost-like or flattened and crushed by compaction (Figure 3d), implying that silicification took place after substantial compaction. The tests rest in a murky, fine-grained matrix composed largely of low birefringent cristobalite, some microcrystalline quartz, and possibly some clay minerals. In addition, there is often a cloudy, very fine-grained, brownish, isotropic material that may be amorphous silica. Very often these zones have what appear to be clots or pellets of the latter material, giving the zone a "dirty" appearance in thin section. Some parts of this zone also contain unreplaced patches of micritic chalk, giving the rock a mottled appearance.

In some of the specimens, the portion of the silicified chalk zone immediately adjacent to the chert zone (described below) contains a fine-grained, yellowish, translucent cement of cristobalite. This cristobalite shows a length-fast fabric parallel to bedding, in contrast to the unoriented fabric of the remainder of the zone.

The contact between the silicified chalk zone and the zone of chert $(\mathrm{CH}$ in Figures $2 \mathrm{a}$ and $2 \mathrm{~b}$ ) is ragged and uneven (Figure $3 \mathrm{~b}$ ). Small patches of white, partly or completely silicified chalk frequently occur within the chert very near this contact (see Figure 2a), and occasionally even larger patches of chalk occur inside the chert (cf. Figure 2a). Macroscopically the chert is dark brown (7.5 YR 4/4), glassy, and has a pronounced conchoidal fracture. In thin section it consists of clear microcrystalline quartz with scattered inclusions (top part of Figure $3 \mathrm{~b}$ ). In plane polarized light the microcrystalline quartz appears very uniform; between crossed polarizers, however, ghost-like outlines of possible microfossils become visible (Figure 3c). Compared to the adjacent silicified chalk zone, the replacement of microfossil tests by silica has been much more intensive, and silicification more complete. Quartz in some of the chert nodules has a preferred orientation, being lengthslow parallel to bedding.

Specific gravity measurements of one specimen gave density values of 2.16 for unsilicified chalk, 2.35 for partly silicified chalk, and 2.61 for the brown quartzose chert. As shown in Figure 1a, the cristobalite of the silicified chalk zone is disordered, with a sharp peak at $21.76 \mathrm{~A}$ corresponding to a $d(101)$-spacing of $4.079 \mathrm{~A}$. The tridymite "shoulder" in the diffractogram of this quartz-rich rock is masked by the quartz peak at $20.86^{\circ} 2 \theta_{0}$.

The zonation discussed above reflects a spectrum of silicification, and the critical zone within this series is the cristobalite-bearing zone of partly to completely silicified chalk (SC and S in Figures 2 and 3). As noted, this zone may contain amorphous silica in addition to cristobalite; but neither the petrographic nor X-ray studies in this investigation has completely clarified the total composition of the zone.

Based on textural and mineralogical evidence in these specimens, it is surmised that some of the key steps in the silicification of chalk ooze and the formation of chert nodules are as follows (see also Heath and Moberly, 1971; Berger and von Rad, 1972; Heath, 1973; Lancelot, 1973; and Greenwood, 1973):

1) Replacement of foraminiferal tests by microcrystalline quartz and filling of large voids (e.g., foraminifera chambers) by chalcedonic quartz.

2) Possibly overlapping with 1 , gradual replacement of the coccolith-rich matrix by disordered cristobalite, and possibly also by amorphous silica.

3) Gradual replacement of the cristobalite-bearing transitional zones by microcrystalline quartz to form 
dense chert with few textural remnants from the original chalk.

The cementation of the adjacent, unsilicified chalk may be related to these silicification processes. Precipitation of small secondary calcite crystals between grains (Figures $7 \mathrm{a}$ and $7 \mathrm{~b}$ ) caused the lithification of the chalk. Calcium and carbonate ions, released through the replacement of calcite by silica, could migrate to adjacent parts of the chalk ooze where saturation concentration would be reached and precipitation of cement would ensue.

\section{DIATOM PORCELANITE, SITE 302}

Silicified porcelanite with very sparse and poorly preserved diatom shells was recovered from the Sea of Japan. Site 302 was located on the northern portion of Yamato Rise, an elongate basement high. The sedimentary sequence cored at this site is composed of various mixtures of diatomaceous ooze and clay. The lithology in contact with the porcelanite is diatom ooze of Miocene age, and this ooze contains well-preserved diatom frustules composed of amorphous silica. A pronounced drop in drilling rate occurred at 270 meters subbottom depths, apparently indicating the top of the silicified layers which form an acoustic reflector. The one sample of porcelanite recovered is a core-catcher sample from 276 meters.

The porcelanite is hard, brittle, and has a vitreous luster and conchoidal fracture. Measured density is 2.00. The rock is irregularly mottled, dark olive-gray (5Y 3/2) to black (5Y 2/2), with a few streaks and discontinuous laminae of olive-gray mudstone; it appears to have been slightly burrowed prior to lithification.

Microscopically the rock consists of $95 \%-98 \%$ of finegrained matrix and less than $5 \%$ pyritized or silicified microfossils (Figure 5c). The latter are largely of indeterminant origin, but those that can be recognized are mostly diatoms, a few foraminifera, and possibly some Radiolaria. Most are molds filled by very fine-grained, clear cristobalite (Figures $6 \mathrm{a}$ and $6 \mathrm{c}$ ), or by amorphous silica. A few molds contain fibrous, length-fast chalcedonic quartz (Figures 5c and 6d).

The predominant matrix is brownish and somewhat specked and has an overall fine streaky appearance (Figures 5c and 6b). Between crossed polarizers the matrix appears to be a cryptocrystalline mixture of isotropic and faintly birefringent material. The former is probably amorphous silica; and X-ray diffraction (Figure 1c) shows disordered cristobalite (lussatite) corresponding to the birefringent material, as well as minor quartz. The cristobalite seems to be clear and has a faint length-slow preferred orientation parallel to bedding. The amorphous silica is very fine grained, and dark gray-brown. Also scattered through the matrix are small amounts of finely disseminated pyrite, brownish material (iron oxides?), and possibly clay minerals.

Details of the matrix become more clearly revealed in acetate peels of polished and etched surfaces (Figures $6 a, 6 c$, and $6 d)$ than in the $30-\mu$ thin sections. In these peels, the outlines of very poorly preserved microfossils, chiefly diatoms, are evident, making it probable that much of the fine-grained matrix observed in thin sec- tions formed by recrystallization of diatom frustules, and possibly other microorganisms.

In scanning electron micrographs the matrix appears as a somewhat ill-sorted, and variable aggregation of poorly defined grains, some of which appear to be platy (Figure 7c). With the higher resolution afforded by the transmission electron microscope, portions of the matrix consist of bladed or platy crystals of inclusionrich cristobalite (Figures $8 \mathrm{a}$ and $8 \mathrm{~b}$ ). Figure lc shows the $\mathrm{X}$-ray pattern of the disordered cristobalite, with the main peak centered at $21.71^{\circ} 2 \theta$ corresponding to a $d(101)$-spacing of 4.090 . Small cavities, probably microfossil molds, are partly filled by lepispheres of cristobalite (Figures 7c and 7d; Wise and Kelts, 1972). However, in contrast to some reports, these spheres compose only a very small proportion of the rock. Oehler (in press) reports similar observations in a cristobalitic porcelanite from the Monterey Formation of California.

This Miocene porcelanite from the Sea of Japan is very similar to certain rocks in the Miocene Monterey Formation of California (Bramlette, 1946), as well as to Miocene siliceous "hard shales" in northwestern Honshu (the Onnayawa Formation and equivalents; see Takahashi, 1922; Taguchi, 1962; Ikeke et al., 1967; Koizumi, 1969). Figure 5d is a microscopic view of a cristobalite-bearing rock from the Monterey Formation (Murata and Nakata, 1974, called this kind of rock "cristobalitic chert"; Bramlette, 1946, earlier used the term "opaline chert"); Figure 1d is an X-ray diffractogram of the rock. In composition and mineralogy, the Monterey "chert" is very similar to the siliceous rock from Site 302, and both rocks are composed largely of a cristobalitic, very fine-grained matrix. The major significant difference is that the Monterey rock contains more microfossils. In both cases, however, it appears likely that the cristobalitic matrix originated by recrystallization of diatom frustules (cf. Bramlette, 1946; Ernst and Calvert, 1969).

\section{CONCLUSIONS}

Major conclusions resulting from this study are:

1) The siliceous rocks recovered on Leg 31 are similar to those cored on numerous other DSDP Legs, and fall into two major categories: (a) Chert nodules in nannofossil chalk ooze (Site 292); (b) Cristobalitic porcelanites associated with brown clays or siliceous biogenic oozes; two varieties were recovered, radiolarian porcelanite (Site 291) and diatom porcelanite (Site 302).

2) Each of these three varieties of siliceous rock is closely similar to sedimentary units found on land. Some examples: (a) The late Eocene chert nodules of Site 292 closely resemble the flint nodules in the Upper Cretaceous chalks of western Europe (Rutten, 1957; Smith, 1960; Buurman and Van der Plas, 1971). (b) The middle Eocene radiolarian porcelanite is very similar to bedded geosynclinal cherts (Grunau, 1965), particularly red radiolarian cherts in the Mesozoic Franciscan Formation of California (Davis, 1918; Bailey et al; 1964). (c) The late Miocene diatom porcelanite of Site 302 very closely resembles cristobalite-bearing cherts and 
porcelanites in the Miocene Monterey Formation of California (Bramlette, 1946; Ernst and Calvert, 1969; Murata and Nakata, 1974; Oehler, in press). They are also similar to siliceous rocks of Miocene age in northern Honshu (Takabashi, 1922; Ikebe et al., 1967).

3) The origin of the abundant, fine-grained, cristobalitic matrix in the diatom and radiolarian porcelanite is not certain. Limited textural evidence suggests the matrix in the diatom porcelanite may be in large part the product of diagenetic recrystallization of diatom frustules. Since the diatom porcelanite presently occurs at only 276 meters subbottom depth, such recrystallization need not imply very deep burial.

4) In contrast with most ancient siliceous rocks which are composed of chert (with exceptions like cristobalitic rocks in the Monterey Formation), the siliceous rocks found on Leg 31 contain abundant disordered cristobalite. Flörke (1955) suggested that progressive ordering of disorderd cristobalite causes a decrease in $d(101)$. This observation was confirmed through work on the Monterey Formation by Murata and Nakata (1974), who stated that "the numerical value of the cristobalite $d(101)$ spacing in angstroms seems to be a useful index of the structural state." They proposed a numerical notation of $\mathrm{Cr}(d(101))$, and using their system, the following values are for Leg 31 samples:

Site 292, nodular chert $\mathrm{Cr}(4.079)$

Site 291, radiolarian porcelanite $\mathrm{Cr}(4.083)$

Site 302, diatom porcelanite $\mathrm{Cr}$ (4.090)

The diatom porcelanite thus contains the least-ordered cristobalite, the nodular chert the most ordered.

5) The kinds of siliceous rocks recovered from marginal seas during Leg 31 have also been cored from the major ocean basins during other DSDP legs. Thus they are in no sense unique to the marginal sea setting, although diatom porcelanite like that at Site 302 seems to have been encountered relatively infrequently during coring in the major ocean basins.

\section{ACKNOWLEDGMENT}

Laboratory work was supported by Grant PRF 5962-AC2 from the Petroleum Research Fund, administered by the American Chemical Society. Grateful acknowledgment is made to the donors of this fund.

\section{REFERENCES}

Bailey, E.H., Irwin, W.P., and Jones, D.L., 1964. Franciscan related rocks and their significance in the geology of western California: Calif. Div. Mines Geol., Bull., v. 183, p. 1.

Berger, W.H. and von Rad, U., 1972. Cretaceous and Cenozoic sediments from the Atlantic Ocean. In Hayes, D.E., Pimm, A.C., et al., Initial Reports of the Deep Sea Drilling Project, Volume 14: Washington (U.S. Government Printing Office), p. 787.

Bramlette, M.N., 1946. Monterey Formation of California and origin of its siliceous rocks: U.S. Geol. Surv. Prof. Paper 212, p. 1.

Buurman, P. and Van Der Plas, L., 1971. The genesis of Belgian and Dutch flints and cherts: Geol. en Mijn., v. 50, p. 9.

Calvert, S.E., 1974. Deposition and diagenesis of silica in marine sediments. In Hsu, K.J. and Jenkyns, H.C. (Eds.),
Pelagic sediments: On land and under the sea: Spec. Publ. Int. Assoc. Sedimentologists, v. 1, p. 273.

Davis, E.F., 1918. The radiolarian cherts of the Franciscan group: Calif. Univ., Dept. Geol. Bull., v. 11, no. 3, p. 235.

Ernst, W.G. and Calvert, S.E., 1969. An experimental study of the recrystallization of porcelanite and its bearing on the origin of some bedded cherts: Am. J. Sci., v. 267A, p. 114.

Flörke, O.W., 1955. Zur Frage des "Hoch"-Cristobalits in Opalen, Bentoniten und Gläsern: Neu. J. Mineral. Mh., v. 10 , p. 217.

Greenwood, R., 1973. Cristobalite: its relationship to chert formation in selected samples from the Deep Sea Drilling Project: J. Sediment. Petrol., v. 43, p. 700.

Grunau, H.R., 1965. Radiolarian cherts and associated rocks in space and time: Ecolog. Geol. Helv., v. 58, p. 157.

Heath, G.R., 1973. Cherts from the Eastern Pacific, Leg 16, Deep Sea Drilling Project. In van Andel, T.H., et al., Initial Reports of the Deep Sea Drilling Project, Volume 16: Washington (U.S. Government Printing Office), p. 609.

Heath, G.R. and Moberly, R.J., Jr., 1971. Cherts from the Western Pacific, Leg 7, Deep Sea Drilling Project. In Winterer, E.L., Riedel, W.R., et al., Initial Reports of the Deep Sea Drilling Project, Volume 7: Washington (U.S. Government Printing Office), p. 991.

Ikebe, Y., Ishiwada, Y., and Kawai, K., 1967. Petroleum geology of Japan: United Nations ECAFE, Min. Res. Devel. Ser., v. 26, p. 225.

Keene, J.N. and Kastner, M., 1974. Clays and formation of deep-sea chert: Nature, v. 249, p. 754.

Koizumi, I., 1969. Tertiary diatom flora of Oga peninsula, Akita Prefecture, northeast Japan: Sci. Rept., Tohoko Univ., Ser. 2, v. 40, p. 171.

Lancelot, Y., 1973. Chert and silica diagenesis in sediments from the central Pacific. In Winterer, E.L., Ewing, J.I., et al., Initial Reports of the Deep Sea Drilling Project, Volume 17: Washington (U.S. Government Printing Office), p. 377 .

Murata, K.J. and Nakata, J.K., 1974. Cristobalitic stage in the diagenesis of diatomaceous shale: Science, v. 184, p. 567.

Oehler, J.H., in press. Origin and distribution of silica lepispheres in porcelanite from the Monterey Formation of California: J. Sediment. Petrol.

Pimm, A.C., Garrison, R.E., and Boyce, R.E., 1971. Sedimentology synthesis: lithology, chemistry and physical properties of sediments in the northwestern Pacific Ocean. In Fischer, A.G., Heezan, B.C., et al., Initial Reports of the Deep Sea Drilling Project, Volume 6: Washington (U.S. Government Printing Office), p. 1131.

Rutten, M.G., 1957. Remarks on the genesis of flints: Am. J. Sci., v. 255 , p. 432.

Smith, W.E., 1960. The siliceous constituents of chert: Geol. Mijn., v. 39, p. 1.

Taguchi, K., 1962. Basin architecture and its relation to the petroleum source rocks developed in the region bordering Akita and Yamagata Prefectures and adjoining areas, with special reference to the depositional environment of petroleum source rocks in Japan: Sci. Rept., Tohoko Univ., 3rd Ser., v. 7, p. 293.

Takahashi, J., 1922. The marine Kerogen Shales from the oil fields of Japan, a contribution to the study of the origin of petroleum: Sci. Rept., Tohoko Univ., Ser. 3, no. 1, p. 63.

Towe, K.M., 1962. Clay mineral diagenesis as a possible source of silica cement in sedimentary rocks: J. Sediment. Petrol., v. 32, p. 26.

Wise, S.W. and Kelts, K.R., 1972, Inferred diagenesis history of a weakly silicified deep sea chalk: Gulf Coast Assoc. Geol. Soc. Trans., v. 22, p. 177. 